\title{
The gospel in context: Hiebert's critical contextualisation and charismatic movements in Sierra Leone
}

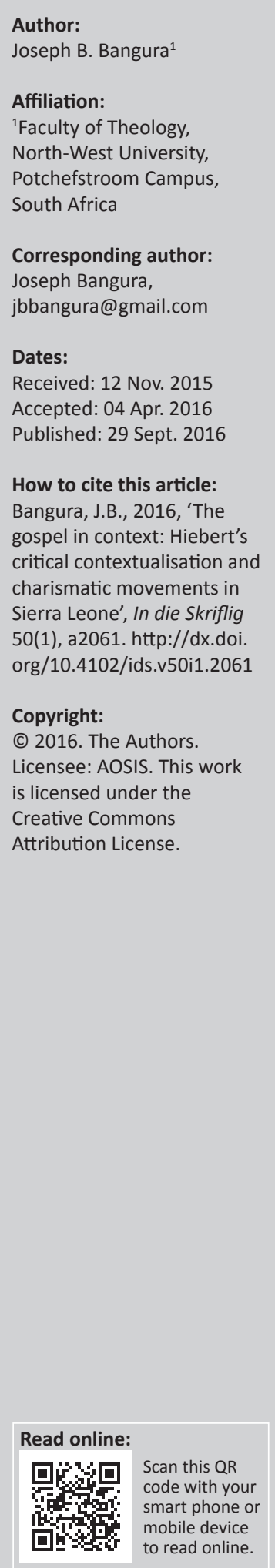

This article examines the process of contextualisation adopted by charismatic movements (CMs) in Sierra Leone. In it I use Hiebert's model of critical contextualisation to evaluate the biblical depth and cultural sensitivity of the CMs' contextualisation. Three ongoing cultural issues are especially highlighted as crucial and are used as the point of departure in the discussions: initiation ceremonies, polygamous marriage practices and ancestral rituals. The article concludes that, whilst the danger of syncretism is likely to occur where uncritical forms of contextualisation are employed, the CMs in Sierra Leone are attempting to address themes that are concurrent with the African sensibilities of its followers. This is an effort to build authentic forms of Christianity that are faithful to Holy Scripture and relevant to the setting in which they are developed.

\section{Introduction, scope and methodology}

Two hundred years after Christianity arrived in Sierra Leone, the oldest Protestant missionary field in West Africa, the country is once again experiencing a revival of the faith (Olson 1969; Shyllon \& Anthony 2008). This time, however, indigenous agents rather than foreign missionaries are responsible for the revival and growth of Christianity. This revival is predicated upon charismatic movements (CMs) whose church-planting efforts that started in the late 1980s are beginning to have an impact on specific issues in Sierra Leone's cultures. However, because there is a wide variety of independent churches, ministries and networks that are often included in most scholarly definitions of African CMs, it will be proper to put forward a definition that elucidates the meaning of the term used here to guide the discussion in this article.

Any discussion about the rise of CMs in Sierra Leone, as it is the case elsewhere in Africa (Lindhardt 2014:10), requires that a definition and delimitation be put forward to clarify the meaning of the term as used in this article. In the scholarly literature, there are generally two broad categories that define the term. The first meaning of the CMs refer to the charismatic revival that occurred in historic mainline churches and denominations in the 1960s (Hocken 2009:29), the most prominent of which was the Reverend Dennis J. Bennett's admission at St. Mark's Episcopal Church in Van Nuys, California, that he had experienced the baptism of the Holy Spirit (Bennett 1982:82-83). This prompted a flurry of confessions from those who had also received the baptism of the Holy Spirit, but had chosen to remain as communicant members of those historic denominations (Van der Laan 2010:204; Menzies \& Menzies 2000:17). These historic churches that had been affected by this charismatic renewal are not discussed in this article. A second meaning refers to independent charismatic churches, ministries and networks that developed outside of classical Pentecostalism, or historic missionary and mainline churches from the late 1970s to the present. This new development within the African church context has been variously described as neo-Pentecostal, charismatic, and neo-charismatic churches or simply CMs (Anderson 2001:15-20; Anderson 2014:114; Mwaura 2004:96-101; Ojo 2006:1). Following the sense suggested by this second definition and given that these new churches, ministries and networks were described as CMs ever since they emerged in Sierra Leone in the 1980s, this article chooses to refer to these churches, ministries and networks as CMs.

African CMs are known to emphasise divine healing, miracles, demons and exorcism, dreams and their interpretation, prophecy, prosperity, anointing with olive oil and differentiating between spirits (Asamoah-Gyadu 2013; Clarke 2014). These churches are most active in urban centres where they have a large following amongst the educated African élite who feel that the movement's spirituality makes sense, addresses unresolved questions and enhances the cultural worldview of 
this constituency (Anderson 2014:135). The burgeoning of CMs in urban centres allow the movement to use contemporary media technologies to spread its message of prosperity, healing and spiritual power to a much wider audience. These charismatic churches appear to be addressing themes that are concurrent with the African cultural sensibilities of its urban élite and youthful followers. Whilst the cultural themes are themselves not new, the responses offered by key leaders of the movement are certainly new. This does not surprise us because the growth of Christianity in the southern hemisphere implies that '... what is to be expected from the South is a theology that addresses the setting in which it is produced' (Walls 1996:9-10).

Given that charismatics are the most enthusiastic Christians on the African continent (Anderson 2004:159; Hylson-Smith 2007:139), and bearing in mind that these '... rising churches usually preach a strong and even pristine Christian message' (Jenkins 2002:126), researchers are beginning to take interest in the theological practices of the movement. Amongst other theological markers, African charismatics employ exuberant and highly engaging sessions of praise and worship, complete with live bands and loud music (Kalu 2008:263). During worship services, church members use the name of Jesus to bind and cast out demonic forces and evil spirits that might want to obstruct spiritual and material prosperity and deny members the healing they so desperately desire (Freeman 2012:13). Charismatics are described as Bible-believing and Holy Ghost-anointed churches '... who do not compromise on the divinity and sacredness of the Bible' (Asamoah-Gyadu 2013:166). Bible reading functions as a repository of narratives that impacts directly on the life of the individual believer (Gifford 2005:86). Church members are often anointed with consecrated olive oil which is said to enhance their ability to display exceptional spiritual power. This anointing capacitates them so that they are able to ward off attacks from the devil and his legion of demons. It is also said to give them victory in spiritual warfare. Followers of these new Christian movements believe that there are spiritual causes for every physical occurrence in life (John 1997:131). This faith recognises the abstruse presence of demonic forces whose intent is to hamper human flourishing (Van der Meer 2010:158). The popularity of Charismatic theological practices suggest that there were historically unresolved questions within the churches that are now been addressed by charismatic churches (John 1997:134).

As Christianity continues to grow in Africa, new missiological questions arise about how to apply the Christian faith to the existing cultural issues. These questions are meant to enable the African church to become faithful to biblical Christianity and relevant to the local cultural context in which the faith is expressed. In Sierra Leone, CMs are attempting to interpret afresh the relationship they believe should exist between the gospel and traditional cultures (Bangura 2013:163). However, this charismatic attempt to relate Christianity to culture has not been subjected to scholarly research, although many Christians subscribe to the core doctrines of spiritual power, deliverance from demonic oppression and prosperity espoused by the movement.

As a consequence, the scope of the article is to examine the critical contextualisation adopted by CMs in Sierra Leone. I do this in three ways. Firstly, I examine Paul Hiebert's model of critical contextualisation as a viable tool for understanding the process of contextualising the gospel. Secondly, I profile three crucial issues (initiation ceremonies, marriage practices and ancestral rituals) in Sierra Leone's cultures that continue to impact church ministry. Thirdly, using Hiebert's model of critical contextualisation, I discuss the reasons why charismatics believe that their attempts at contextualising the gospel are proving useful for the church and pastoral ministry context in Sierra Leone.

In terms of methodology, this article grew out of my 2013 doctoral dissertation, a study which was based on a missiological analysis of the CMs in Sierra Leone. In it I analyse Hiebert's model of critical contextualisation in dialogue with the contextualisation and church ministry contexts of CMs in Sierra Leone. As part of this endeavour, I undertook three field research trips to Sierra Leone where interviews with key leaders of the movement were conducted. This process gave me unhindered access to material and books published by the leading advocates of the movements which were used to evaluate the CMs' contextualisation (Cole 1999; Laggah 2003; Mambu 2011).

\section{Critical contextualisation}

Contextualisation has been an ongoing theme in missiological discourse. When the term first emerged in the 1960s from its ancestry in the conciliar movement (Hesselgrave \& Rommen 1989:27-35), it was suggested as better suited to correct the limitations created by the inability of Western theology to understand the cultures and contexts of non-Western churches and thus leverage the drawback of earlier models such as inculturation, enculturation, translation and indigenisation, amongst others (Magesa 2004; Sanneh 1989; Schineller 1990). More than this was the admission that contextualisation took provenance over other models because of its inability to respond to the social and cultural changes that have occurred in the African or Latin American mission fields (Bevans 2002:26-27). Contextualisation refers to an ongoing process where the gospel is assimilated into the total life of the people in their cultural context so that the message makes sense to those who profess it (Bosch 1983:495; Flemming 2005:13-14; Bevans 2002; Whiteman 1997). For this process of contextualisation to be effective, it has to ensure that it guards against leading the Church away from biblical truth by facilitating the emergence of a form of Christianity that makes sense to people. However, in doing this, the danger of syncretism is likely to occur, especially if the extent to which the church can contextualise the gospel has not been clearly identified (Greenfield \& Droogers 2001).

Although contextualisation is an ongoing theme in missiology, little effort has been made to apply specific 
models of contextualisation to the church contexts of CMs in West Africa. Mindful of the risk of oversimplification, the specific experiences of charismatics in Sierra Leone make this statement much more justifiable. Whilst CMs have moved from an initial peripheral position to become a major factor that determines the course of Christianity in Sierra Leone, as it is in much of sub-Saharan Africa (Lindhardt 2014:1), little research has been carried out that shed light on this charismatic resurgence of the Christian faith, or its efforts to contextualise the gospel.

In Sierra Leone, it is only John (1997:129-137) who attempted to situate the role played by charismatics as they seek to foster community and cohesion within the group in a chapter on 'Charismatics and Community'. Even Shyllon (2008:234), Sierra Leone's leading Church historian, only mentions the movement in passing, adding that it is known to be embroiled in feuds that often lead to splinters and schisms, as well as being accused of involvement in proselytising and sheepstealing from mainline denominations. Although insightful, these studies are bereft of answers to questions of history and contextual theological practices of the movement. It is this absence of critical missiological research on the charismatic churches in Sierra Leone that inspired me to attempt to respond to the problem of the movement's contextualisation.

It was Paul Hiebert who introduced the model of 'critical contextualization' to missiology. Hiebert (1984) affirms that as the gospel advances to foreign geographic territories, new methods are bound to arise that help the church to effectively contextualise the gospel. In this model, Hiebert notes that the growth of the church in new cultural contexts always raises challenges for the gospel. This model, Hiebert submits, guards against the ethnocentricism and cultural foreignness that non-contextualisation creates and it prevents newly founded churches from relapsing into relativism and syncretism when extreme forms of contextualisation are uncritically adopted (Hiebert 1987:109). As Hiebert reminds us, '... the gospel is not simply information to be communicated. It is a message to which people must respond' (Hiebert 1987:110). Those who come to faith in Christ are expected to live in the light of their newly found faith. This may require that converts sever old ties, adapt old ways to new contexts or make a permanent and complete break with past traditions altogether. The Christian missionary therefore has to exercise great caution whilst communicating this message and inviting people to faith in Jesus Christ.

By guarding against these two extremes (ethnocentricism and culturalforeignness) that often challengecontextualisation, Hiebert's model offers four steps that the church can take to incarnate the gospel in its new cultural context. These are: exegesis of the culture; exegesis of the scripture and the hermeneutical bridge; critical response; and the development of new contextualised practices (Hiebert 1987:109-112). These steps require the total participation of African converts with the missionary, as new converts study their culture in light of scripture to build up the faith in a manner that is grounded in and faithful to the Bible (Clarke 2014:29-34; Asamoah-Gyadu 2013:166; Anderson 2014:63).

\section{Cultural practices in Sierra Leone}

The Republic of Sierra Leone, situated in West Africa has a population of 7 million. Sierra Leoneans are a deeply religious people (Featherstone 2015:1). Although precise statistics about the religious percentage share are hard to come by, estimates indicate that between $40 \%$ to $60 \%$ of the population are Muslims and $30 \%$ to $40 \%$ follow various versions of African traditional beliefs. The remaining $15 \%$ to $20 \%$ identify themselves as Christians, with about $7 \%$ subscribing to newer charismatic and Pentecostal beliefs (Pew Research Centre 2015:242). The variability in the figures is an indication of the level of inter-religious tolerance and peaceful coexistence people enjoy in the country (Featherstone 2015:18). In spite of the lower percentage of Christians, the country's historic role in the spread of Christianity is impeccable. As a former crown colony for British rule in West Africa, Sierra Leone's Krio people played a pivotal role in the early diffusion of Christianity across West Africa (Sanneh 1983:73; Walls 1996:103-104; Hanciles 2002:13; Hastings 1979:40). Today, whilst Christianity is reinventing itself with the founding and development of independent churches, ministries and networks that clearly espouse pneumatic tendencies, culture continues to be a hindrance to the authentic experience of the Christian faith.

Sierra Leone's 14 ethnic groups practise cultures that have similar characteristics. These cultures define acceptable traditions and norms that its people are expected to follow. They lend credence to the identity of persons and demarcate their place in the wider community. Because these traditional practices preceded the advent of Christianity and Islam in Sierra Leone, when people convert to Christianity, their personal or communal experiences as Christians are normally assessed against their cultural backgrounds (Kruetzinger 1966). It is, therefore, necessary that these cultures and traditions are subjected to careful analysis so that we can better understand the $\mathrm{CMs}^{\prime}$ contextualisation. Three of the most pervasive cultural practices are discussed below.

\section{Initiation ceremonies}

Amongst the Temne ethnic group of northern Sierra Leone, the age of puberty signifies the occasion when initiation rites are performed. These rites which take place at a secret society bush, include the rite of male circumcision and female genital mutilation (FGM) (Fanthrope 2007:1-2). Given the controversy over this cultural practice, I shall focus briefly on the female Bondo secret society where FGM is performed (Schimmel 2007). At puberty, young girls are sent to the digba, a revered female traditional leader who also doubles as a traditional midwife, to go through genital cutting. Working with trusted female traditional elders, the digba receives the bora (financial token) from the parents of the young girls through the chiefdom elders. She prepares the girls for initiation rites, performs the cutting of the labia 
minora and supervises every stage of the initiation ceremony (MacCormark 1979:32). The new initiates, who are kept in isolation throughout the process, are only presented back to the community upon the successful completion of all initiation rites. When enacting her roles, the digba serves as the official representative of the community of elders, which comprises the living and ancestors. The entire initiation ceremony is intended to train young initiates to develop kinship ties with age mates, identify their place within the community and acquire skills that will help them to meaningfully participate in the cohesion of the community as responsible adults. It is the responsibility of the digba to imbibe in the young girls the skills necessary for service as elder sisters, wives, and mothers. Unless young girls complete initiation ceremonies of the Bondo secret society, they will not be married off or perceived as responsible adults (Davies 2009). Non-initiates are often subjected to ridicule and ostracisation by peers.

\section{Marriage patterns}

Sierra Leoneans share a deep sense of allegiance to their family. Family life includes more than father, mother and children. The belief amongst them is that human life should not be lived outside of the community. A life lived in seclusion is unthinkable. In any given single home, there would be at least three generations of people present - grandparents, parents, and children. The family unit can best be described as an extended family, rather than a nuclear family (Featherstone 2015:1). In such circumstances, the practice of polygamy is a traditionally accepted norm that governs family and community life. Although this practice is much more prevalent amongst people living in the traditionally conservative rural regions of Sierra Leone, those who migrate to settle in urban centres still have the inclination to continue this tradition. The 2004 National Population Census indicates that $18.31 \%$ of the national population is living in polygamous households (Thomas, MacComock \& Bangura 2007:7). Amongst the Temne, Mende and Limba people, polygamy accords men the right to marry many wives. There are no limits that are imposed on the number of wives the husband is allowed to have, as long as he is able to pay the dowry. There are a number of reasons that lead to polygamy. Prominent amongst the reasons why the practice of polygamy is allowed is procreation. Amongst the Temne, although families need to grow in number, childbearing is not allowed outside marriage. If after contracting a marriage, the wife fails to bear children, tradition allows the husband in consultation with his family along with the first wife, to look for a second wife. The second wife is usually expected to bear children for that family. The search for the co-wife is carried out from the same clan, village or region where the husband originated. All the traditional rights that go with marriages are performed fully for the second wife. Other reasons for the prevalence of polygamy may include agricultural productivity, the right to become a member of a traditional ruling family or even for purely personal reasons. New advocates for the continuation of traditional marriage practices emerge with an ever increasing frequency.

\section{Ancestral rituals}

Ancestors play an important role in the traditional world view of Sierra Leone. The belief that ancestors continue to exist after death in the world of the 'living dead' remains an integral part of what sustains the well-being of the community (Sawyerr 1966:30). The ancestors are the rock from which the present generation is hewn. Therefore, they wield enormous influence on their surviving relatives, so much so that it is well nigh impossible to set them aside. To do this will be equivalent to depleting that community of its roots in the past, denying its culture and smearing its dignity (Conteh 2009:37). This view of the ancestors held by Sierra Leone's traditionalists points to two rites that must be upheld if surviving relatives desire to continue enjoying the protection, provision and good will of the ancestors (Foullah 2000:73). Traditionally, death does not end human life. Death is transitory, possessing the power to usher persons from a state of physical existence to one that is spiritual. Although the dead are believed to be spatially living in the abode of their graves, they continue to exist as real spiritual beings in the world of the living dead. That is why people who hold to this traditional world view have a clear sense of a place where they believe the ancestors presently live. The Krio for instance, believe that at death the ancestors proceed from physical existence to live in the 'world of truth.' Here they do not suffer from the corrupting effects of deception which blight human societies because they now know reality (Sawyerr 1966:43). The Mende believe that their dead are 'living in God's bosom' (Yambasu 2002:64). Both the Limba and Temne believe that the ancestors 'live in the place of the dead' (Conteh 2009:38-39). This abode does not suggest any inability to act, but from this place of the dead, the ancestors are better able to monitor, control and/or change the course of events amongst their living relatives. Thus, ancestors are always consulted when important life events are celebrated.

\section{Charismatics, culture and critical contextualisation}

Sierra Leoneans are fascinated with continuing certain cultural practices even after conversion (Davies 2009:1). This grip that culture has on the world view of persons often challenges the Church's missionary approach and its understanding of the faith. Whilst the Church has not projected an unanimous approach to the issue of culture, charismatics are gradually becoming noticeable for their response to specific issues in culture. Bishop Julius Laggah, prelate of Bethel World Outreach Ministries International founded in 1992, believes that every human culture has a repertoire of good aspects and values. He argues further, like many other leaders of the CMs, that the entry of sin into creation distorted those good values and opened them up to demonic influences. Demonic cultures prevent people from coming to faith in Christ. These corrupted human cultures, he argues, must be evangelised and resubmitted to Christ whose redeeming power brings about transformation. Using the passage from Revelation 7:9 where John saw the great 
multitude from every nation, tribe, people and language, Laggah (2003) adds:

The gospel that we are called to preach should transcend cultural and ethnic barriers ... God is interested in the salvation of every culture whether it be African, European, American or Asian culture. (p. 47)

As a consequence, Laggah calls on the churches to be extremely careful in the process of contextualisation to avoid the danger of bringing sinful aspects of traditional cultures, such as initiation ceremonies, polygamy and ancestral rituals, back into the Church.

\section{Charismatics and initiation ceremonies}

Charismatics reject participation in all initiation ceremonies, such as the Bondo secret society where FGM is performed. In his rebuttal of initiation ceremonies, Bishop Jonathan Cole, who founded New Life Ministries International in 1993, reasons that the female Bondo secret society allows people to contract blood covenants with demonic forces. Cole (1999:16-17) sees the Bondo secret society as shrouded in mystery, and argues that the FGM procedure clearly contradicts the teaching of Holy Scripture. Whilst the Bondo secret society may have contributed to the moral development and preparation of young girls so that they are able to perform adult roles, charismatic church leaders such as Pastor Francis Mambu, who founded Faith Healing Bible Church in 1987, believes that the Church has a better alternative for the training of the young. They do this during their annual conferences where special teaching sessions are held on marriage and family life (Mambu 2011:52-58). Charismatics, furthermore, have not hidden their antipathy against attempts made elsewhere in Africa to Christianise initiation ceremonies, the practice of FGM or the entire female Bondo secret society (Schfroth 2009). The antidote to this charismatic aversion to female initiation ceremonies is an intensification of Christian discipleship and Bible training in their churches on topics such as marriage and family life and Christian parenting.

\section{Charismatics and marriage practices}

As noted already, the accepted traditional patterns of marriage and family life are polygamous and extended in nature. The reasons for this are not farfetched because in a society where life is lived in dialogue with others, people exist not as individuals but in collaboration with each other in the community. Nonetheless, in spite of this traditional view on marriage and family life, when the charismatic churches came into the limelight, leaders of the movement showed a very critical and vocal attitude against the practice of polygamy. New Life's Bishop Jonathan Cole (1999:37), using what he describes as the 'law of first mention' which he develops from the Genesis creation narrative, argues against polygamy as a complete breach of God's desire for the institution of marriage. For him, monogamy is God's divine will for the institution of marriage. For Pastor Francis Mambu's Faith Healing Bible Church, marriage is a holy union between one man and one woman. Divorced persons are not allowed to re-marry, nor can believers marry unbelievers (Mambu 2011:25-26).

To build a cohesive community within their churches, charismatics have supported young couples by paying for some of their wedding costs. This emphasis has not only restored ethical civility amongst charismatic married couples, but has also provided paradigms of how to live in the midst of the difficult economic times in Sierra Leone. The impact of this charismatic preference for monogamous marriage and family life, and the support they give to families has brought a number of benefits to the young born-again urban élites, towards whom its ministries are targeted. Firstly, young couples are better able to exercise control over their finances. Secondly, it has also led to the restoration of the dignity of women in what used to be a traditional male-dominated society. And thirdly, as John (1997:135) puts it, ' ... women are not abused by their men, and they do not compete with other women (particularly the in-laws) for the affection of their husbands.'

\section{Charismatics and ancestral rituals}

Whilst charismatics agree that the memory of the dead is to be cherished, and although the movement has ensured that welfare funds (such as the death benefit fund) are created to support families when death occurs, they have also been clear in expressing complete repugnance for specific ancestral rituals (John 1997:135-136). From their reading of Holy Scripture, African charismatics like other Christians in Africa, argue that the believer is not allowed to offer animal sacrifices or bring libation to the ancestors (Dt 26:14). This is because by his death and resurrection, Jesus Christ has offered the perfect sacrifice that has atoned for human $\sin$ (Heb 9:26). This recognition means that charismatics believe that there is no other person or spirit who qualifies as intermediary between God and his people, other than Jesus Christ. Furthermore, charismatics believe that the Bible strongly prohibits contacting the dead by invoking their spirits and seeking counsel from them (Dt 18:10-11). Although some hard line traditionalists have accused charismatics of fragmenting traditional values by this strict stance against rituals like ancestral sacrifices, the movement is neither perturbed nor deterred in its resolve to remain faithful to the scriptures (John 1997:136).

\section{Hiebert's critical contextualisation}

Having examined the charismatic responses to Sierra Leone's ongoing cultural issues, is there a basis on which these charismatic contextualised practices can be applied to the model proposed by Hiebert's? Four perspectives will help shed light on the link between them.

Firstly, Hiebert contends that this model seriously regards the efficacy of the gospel and the essential nature of human cultures in understanding the gospel. To allow this to happen in a specific mission context, an exegesis of both culture and 
the scriptures is required. African charismatics like other Christian groups, take Holy Scripture seriously and wants to communicate in ways that are just and fair to the recipient culture (Lindhardt 2014:64-65; Asamoah-Gyadu 2013:168). Therefore, their reading of the Bible leads them to reject FGM, polygamous marriage practices and ancestral rituals. This is a bold step and demonstrates seriousness, the kind of which is poised to build a healthy church. The movement wants to send a clear message that they are on a mission that is reshaping the Christian faith in Sierra Leone.

Secondly, Hiebert's model does not pre-judge which aspects of human cultures are considered useful. Rather, applying the model requires the missionary to work with people so that they are able to study their own culture carefully and come up with what is relevant to their context. The purpose of the study of culture is to understand the old ways, not to judge them (Hiebert 1987:109). Through the marriage and family life seminars, charismatics appear to have led the way in identifying certain aspects of culture that limit the authentic expression of the gospel in ways that are relevant to their context. Consequently, these aspects have been critically disposed of by the CMs.

Thirdly, critical contextualisation uses tools from the Bible and human culture to construct a theology that is both relevant to the Church and makes sense to people. By using scripture to evaluate elements within their cultures, the Church grows in its ability to discern truth (Hiebert 1987:110). As a people who love the Bible, the charismatics' use of the scriptures helps them to better understand their cultures and discern how the truth of the gospel applies to this reality. For instance, Bishop Cole's 'law of first mention' is presently shaping the movement's approach to marriage and family practices.

Fourthly, this model allows the Church to claim ownership of its ministry praxis rather than to depend on external imposition, no matter how well-meaning such imposition may have been. In view of the fact that it is the Church that developed these new contextualised practices, those practices will be Christian because they explicitly seek to express biblical teaching. They will also be contextual, because they were created by the Church using forms that are understandable to people in their given context (Hiebert 1987:110). Consequently, charismatic theological practices are becoming the sine qua non for the urban elite members of the movement.

\section{Conclusion}

This article presented the contextual theological approaches of charismatics to specific issues in the cultures of Sierra Leone. The rise of charismatic churches brought a new indigenous Christian approach that attempts to interpret afresh the relationship that should exist between the gospel and human cultures. This process of contextualisation involves applying the gospel to a specific cultural context so that biblical Christianity can make sense to people. However, in striving to contextualise, the Church must guard against the kind of theologising that merely reinforces the cultural practices of people. When the Church uses African culture in this way without recourse to a serious study of Holy Scripture, contextualisation will certainly spell syncretistic doom for the Church. The Church is called to use Holy Scriptures in its evaluation of the themes that are entrenched in African culture. This critical model of contextualisation, if used properly, may potentially build authentic forms of Christianity that are faithful to the scriptures and are effectively disposed to address the cultural context of Sierra Leone. However, this process has not always been easy for the African Church. Critical contextualisation calls into question the extent to which the Church is allowed to go in its process of contextualising the gospel without losing the essential components that are contained therein. By its objection and critical attitude towards traditional initiation ceremonies, polygamous marriage practices and ancestral rituals, CMs may be helping the churches to be more effective in their ministries. These attempts should be regarded as mediating a revival where churches and other Christian groups can make a spiritual and moral impact on those communities where they minister across Sierra Leone.

\section{Acknowledgements Competing interests}

The author declares that he has no financial or personal relationships which may have inappropriately influenced him in writing this article.

\section{References}

Anderson, A.H., 2001, African reformation: African initiated Christianity in the 21st century, Africa World, Trenton.

Anderson, A.H., 2004, An introduction to Pentecostalism: Global charismatic Christianity Cambridge University Press, Cambridge.

Anderson, A.H., 2014, An introduction to Pentecostalism: Global charismatic Christianity, 2nd edn., Cambridge University Press, Cambridge.

Asamoah-Gyadu, J.K., 2013, Contemporary Pentecostal Christianity: Interpretations from an African context, Wipf \& Stock, Eugene.

Bangura, J.B. 2013., The charismatic movement in Sierra Leone 1980-2010: A missiohistorical analysis in view of African culture, prosperity gospel and power theology, PhD thesis, ETF Leuven, VU University, Amsterdam.

Bennett, D.J., 1982, Nine o'clock in the morning, Kingsway Publication, Eastbourne.

Bevans, S.B., 2002, Models of contextual theology, rev. exp. edn., Orbis Books, Maryknoll.

Bosch, D.J., 1983, 'An emerging paradigm for mission in the Third World', Missiology:An International Review 11, 485-510.

Clarke, C.R., 2014, 'Call and response: Towards an African Pentecostal theological method', in C.R. Clarke (ed.), Pentecostal theology in Africa, Pickwell Publishers, Eugene.

Cole, J.A., 1999, Devil demons and deliverance, New Life Publication, Freetown.

Conteh, P.S., 2009, Traditionalists, Muslims, and Christians in Africa: Interreligious encounters and dialogue, Cambria Press, Amherst.

Davies, J. E., 2009, The Church and the secret society syndrome in Sierra Leone, The Evangelical College of Theology, Freetown.

Fanthrope, R., 2007, Sierra Leone: The influence of secret societies with special reference to female genital mutilation, Writenet Independent Analysis Paper, London.

Featherstone, A., 2015, Keeping the faith: The role of faith leaders in the ebola response, CAFOD Joint Publication, London.

Flemming, D.E., 2005, Contextualization in the New Testament: Patterns for theology and mission, InterVarsity Press, Downers Grove.

Foullah, L., 2000, Administering the local church, Mount Aureol Publishers, Freetown.

Freeman, D., (ed.), 2012, Pentecostalism and development: Churches, NGOs and social change in Africa, Palmgrave Macmillan, Basingstoke. 
Gifford, P., 2005, 'A view of Ghana's new Christianity', in L.O. Sanneh \& J.A. Carpenter (eds.), The changing face of Christianity Africa, the West, and the world, pp. 81-96, Oxford University Press, New York.

Greenfield, S.M. \& Droogers, A.F., 2001, Reinventing religions: Syncretism and transformation in Africa and the Americas, Rowman \& Littlefield, Lanham.

Hanciles, J., 2002, Euthanasia of a mission African church autonomy in a colonial contex, Praeger, Westport.

Hastings, A., 1979, A history of African Christianity, 1950-1975, Cambridge University Press, Cambridge.

Hesselgrave, D.J. and Rommen, E., 1989, Contextualization: Meaning, methods and models, Baker, Grand Rapids.

Hiebert, P.G., 1984, 'Critical contextualization,' Missiology: An international review 12, 287-296.

Hiebert, P.G., 1987, 'Critical contextualization', International Bulletin of Missionary Research 11, 104-112.

Hocken, P., 2009, The challenges of the Pentecostal, charismatic and messianic Jewish movements: The tensions of the spirit, Ashgate, Farnham.

Hylson-Smith, K., 2007, To the ends of the earth: The globalization of Christianity, Paternoster, London.

Jenkins, P., 2002, The next Christendom: The coming of global Christianity, Oxford University Press, Oxford.

John, I., 1997, 'Charismatics and community', in J. Parratt (ed.), A reader in African Christian theology, pp. 129-139, SPCK, London.

Kalu, O., 2008, African Pentecostalism: An introduction, Oxford University Press, Oxford. Kruetzinger, H., 1966, The Eri devils in Freetown, Sierra Leone, Osterreichische Ethnologische Gesellschaft, Vienna.

Laggah, J., 2003, Missions possible, Christian Literature Crusade Publishing House, Freetown.

Lindhardt, M., (ed.), 2014, Pentecostalism in Africa: Presence and impact of pneumatic Christianity in postcolonial societies, Brill, Leiden/Boston.

MacCormark, C.P., 1979, 'Sande: The public face of a secret society', in B. Jules-Rosette (ed.), The new religions of Africa, pp. 25-40, Ables Publishing Cooperation, Norwood.

Magesa, L., 2004, Anatomy of inculturation: Transforming the church in Africa, Orbis, Maryknoll.

Mambu, F.A.M., 2011, The fifth ministers church growth strategy \& renewal conference, Faith Healing Publications, Grafton.

Menzies W.W. \& Menzies, R.P., 2000, Spirit and power: Foundations of Pentecostal experience, Zondervan, Michigan.
Mwaura, P., 2004, 'African independent churches: Their role and contribution to African Christianity,' in Kwami Bediako et al. (eds.), A new day dawning: African African Christianity, in Kwami Bediako et al. (eds.), A new day dawning: African
Christians living the gospel, essays in honour of Dr. JJ (Hans) Visser, pp. 96-101, Christians living the gospel, ess

Ojo, M. A., 2006. The end-time army: Charismatic movements in modern Nigeria, Africa World Press, Trenton.

Olson, G.W., 1969, Church growth in Sierra Leone: A study of church growth in Africa's oldest Protestant mission field, W.B. Eerdmans Pub. Co., Grand Rapids.

Pew Research Centre, 2015, The future of world religions: Population growth projections, 2010-2050, Pew Research Centre, Washington, D.C. http://www. pewforum.org/2015/04/02/religious-projections-2010-2050/

Sanneh, L.O., 1983, West African Christianity: The religious impact, Orbis Books, Maryknoll.

Sanneh, L.O., 1989, Translating the message: The missionary impact on culture, Orbis Books, Maryknoll.

Sawyerr, H., 1966, 'A Sunday graveside libation in Freetown after a bereavement', Sierra Leone Bulletin of Religion 8(2), 30-50.

Schfroth, V., 2009, 'Female genital mutilation in Africa: An analysis of the church's response and proposals for change', Missiology: An International Review XXXVII(4), 538-539.

Schimmel, B., 2007, Female genital mutilation in Sierra Leone, Deutsche Gesellschaft für Technische Zusammenarbeit, Eschborn.

Schineller, P., 1990, A handbook on inculturation, Paulist, New York.

Shyllon, L.E.T. \& Anthony, G.S., 2008, Two centuries of Christianity in an African province of freedom, Sierra Leone: A case study of European influence and culture in church development, Print Sundries and Stationers, Freetown.

Thomas, A.M., MacComock, V.M. \& Bangura, P.S., 2007, Sierra Leone integrated household survey 2003/2004, Statistics Office, Freetown.

Van der Laan, C., 2010, 'Historical approaches', in A.H. Anderson et al. (eds.), Studying global Pentecostalism: Theories and methods, University of California Press, Berkeley.

Van der Meer, E., 2010, 'Strategic level spiritual warfare and mission in Africa', Evangelical Review of Theology 34, 155-166.

Walls, A.F., 1996, The missionary movement in Christian history: Studies in the transmission of faith, Orbis Books, Maryknoll.

Whiteman, D.L., 1997, 'Contextualization: The theory, the gap, the challenge', International Bulletin of Missionary Research 21, 2-7.

Yambasu, S.J., 2002, Dialectics of evangelization: A critical examination of Methodist evangelization of the Mende people in Sierra Leone, AOG Literature Centre, Accra. 